\title{
Comparative Study between Milligan Morgan and Closed Hemorrhoidectomy With or Without Plication
}

\author{
ALAA A. EL ASHRY, M.D.; MOHAB G. MOSTAFA, M.D.; ASHRAF M.S. ALKINANY, M.Sc. and \\ MOHAMED G. QASSEM, M.D.
}

The Department of General Surgery, Faculty of Medicine, Ain Shams University

\begin{abstract}
Background: Hemorrhoids are considered the most common and troublesome anal disorders. They can slide down, prolapse, dilate, and bleed occasionally.

Aim of Study: To assess the effectiveness of plication in reduction of postoperative pain and bleeding after open and closed hemorrhoidectomy.

Patients and Methods: This study included 100 patients who underwent haemorrhoidectomy at Surgery Department of Ain Shams University Hospitals \& El-Mahalla General Hospital. The participants were divided into four groups: Group 1: Open haemorrhoidectomy without plication, Group 2: Open haemorrhoidectomy with plication, Group 3: Closed haemorrhoidectomy without plication and Group 4: Closed haemorrhoidectomy with plication.

Results: In both close \& open procedures, no patient was pain free. However, Post-operative pain scores were significantly low in the open Group than close Group during first 24 hours. Minimal intraoperative blood loss occurred in 60\%, $64 \%, 72 \% \& 64 \%$ of patients in group $1,2,3 \& 4$ respectively with no significant difference between the 4 groups.

Conclusion: Plication of piles appears to have no significant advantages over conventional methods in terms of patient comfort and incidence of intraoperative \& postoperative complications.
\end{abstract}

Key Words: Milligan morgan-Closed hemorrhoidectomyPlication.

\section{Introduction}

HEMORRHOIDS can be internal or external. External hemorrhoids are distal to dentate line and are covered with endoderm [1].

Millions of people are affected around the world. It is a major medical and socioeconomic problem. The etiology of hemorrhoids includes many factors such as constipation and prolonged straining [2]. The commonest symptom of third

Correspondence to: Dr. Ashraf M.S. Alkinany, E-Mail: drashrafalkinani@gmail.com degree hemorrhoids is bright red blood covering the stool or found on toilet paper after defecation or in the toilet bowl. Other symptoms include sensation of a hard lump around the anus, protrusion, and/or mucous discharge. Frequent rubbing of the anus causes exacerbation of the symptoms with vicious cycle of irritation, itching, and bleeding, which is called pruritus ani. They are liable to thrombosis, causing severe pain [1]

Hemorrhoids are classified into four degrees. The first and second degrees require conservative or semi conservative methods. The third and fourth degrees include severe prolapse and usually require surgical intervention [3]

The indication for hemorrhoidectomy includes third and fourth degree hemorrhoids, second degree hemorrhoids that have not been cured by nonoperative treatment, fibrosed hemorrhoids, internexternal hemorrhoids when external hemorrhoids is well defined and the other strong indication for surgery is haemorrhoidal bleeding sufficient to cause anemia [4].

Hemorrhoidectomy can be performed using an open hemorrhoidectomy (Milligan-Morgan) or closed hemorrhoidectomy (Ferguson technique). Both involve ligation and excision of hemorrhoids. In Milligan and Morgan technique the anal mucosa and skin are left open to heal by secondary intention but in closed technique the wound is sutured [5] Although hemorrhoidectomy is the most effective treatment, the presence of postoperative pain and complications as bleeding is the main reason why patients do not want the operation [6].

There are many reports on advantages of closed d over open technique for the treatment of hemorrhoids such as less blood loss, less pain and better post-operative outcome [7] 
Singh and their colleagues [1] found that both operative procedures i.e. closed technique and open technique are safe and lead to satisfactory results. However, Ferguson procedure is found to cause less postoperative distress, reduced hospital stays and early return to work as healing is faster. The addition of lateral internal sphincterotomy to both the techniques seems to have a positive effect on reducing the post-operative pain and bleeding. While Khubchandani [8] found no difference in post-operative pain relief in open group with internal sphincterotomy and without internal sphincterotomy.

\section{Aim of the work:}

The aim of this study is to assess the effectiveness of plication in reduction of postoperative pain and bleeding after open and closed hemorrhoidectomy.

\section{Objective:}

The correlation between plication and incidence of postoperative pain and bleeding.

\section{Patients and Methods}

This is a prospective randomized control trial non-blinded method study which conducted at Surgery Department of Ain Shams University Hospitals \& El-Mahalla General Hospital from March 2020 to March 2021. The study population was patient with hemorrhoid who were admitted at General Surgery Department. This study used sealed envelopes simple randomization. Each envelope contained a specific type of the four methods of intervention.

Inclusion criteria: Patient with investigatory support to hemorrhoids and willingness for the surgical management, both sex and hemorrhoid grade 3 and grade 4 .

Exclusion criteria: Inflammatory bowel disease, Fissure, Recurrent hemorrhoids, Fistula, Malignancy, Cirrhosis and portal hypertension, Pregnancy and Blood diseases.

\section{Sample size and sampling method:}

Sample size was calculated using the $(\mathrm{G}$ power software). We found 4 groups each one 25 patient with total sample size 100 patient are appropriate sample size for the study The power is $90 \%$ and a error probability $=0.05$.

The magnitude of the effect to be detected was estimated as the mean and standard deviation of the variable of interest and obtained from the scientific literature.

\section{Ethical considerations:}

1- The study protocol was approved by the Institutional Review Board of University of Ain Shams and the Ethics and Research Committees of the Faculty of Medicine, Ain Shams University prior to commencement.

2- Study participants signed informed consent after detailed explanation of the purpose, risks and benefits, confidentiality and rights of participants prior to recruitment.

Study tools and study procedures:

The patients were divided to 4 groups:

1- Group 1: 25 patient with hemorrhoid who underwent the Milligan Morgan procedure with plication.

2- Group 2: 25 patient with hemorrhoid who underwent the Milligan Morgan procedure without plication (conventional controlled group).

3- Group 3: 25 patient with hemorrhoid who underwent closed hemorrhoidectomy with plication

4- Group 4: 25 patient with hemorrhoid who underwent closed hemorrhoidectomy without plication.

All the patients were subjected to:

\section{Preoperative assessment:}

1- Thorough history taking:

- Demographic data: Age, sex, marital status and residence.

- History of previous medications especially thromboembolic medications.

- Past and family history of blood diseases, malignancy, recurrent hemorrhoids and other excluded condition.

2- Clinical examination:

- General examination was performed.

- Local examination to the anus: For detection of grade of hemorrhoids, bleeding and fissure.

\section{3- Investigations:}

- Routine laboratory investigation.

- Specific investigation as: Coagulation and bleeding profile.

- Colonoscopy in cases suspecting have malignancy, inflammatory bowel diseases.

Operation: Group 1: Underwent Milligan Morgan procedure with placation. Group 2: Underwent Milligan Morgan procedure without placation. Group 3: Underwent closed hemorrhoidectomy with placation. Group 4: Underwent closed hemorrhoidectomy without placation. 


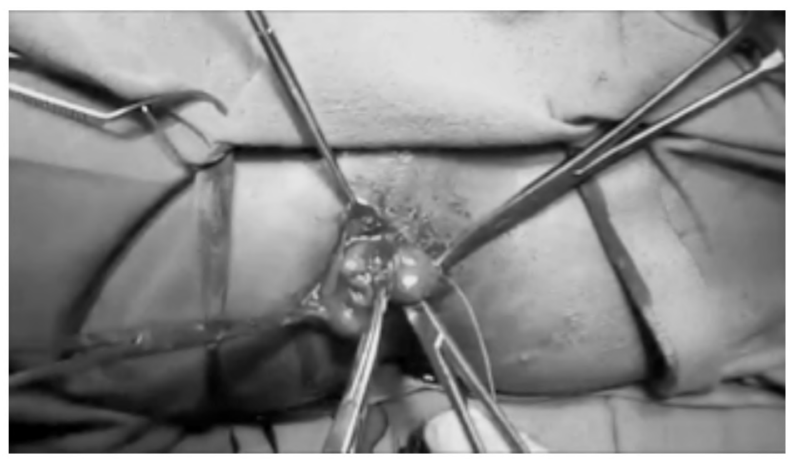

(A)

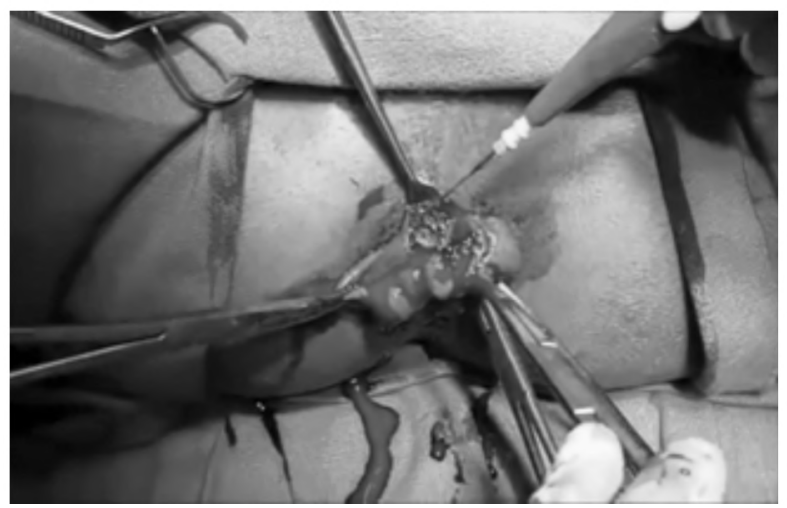

(C)

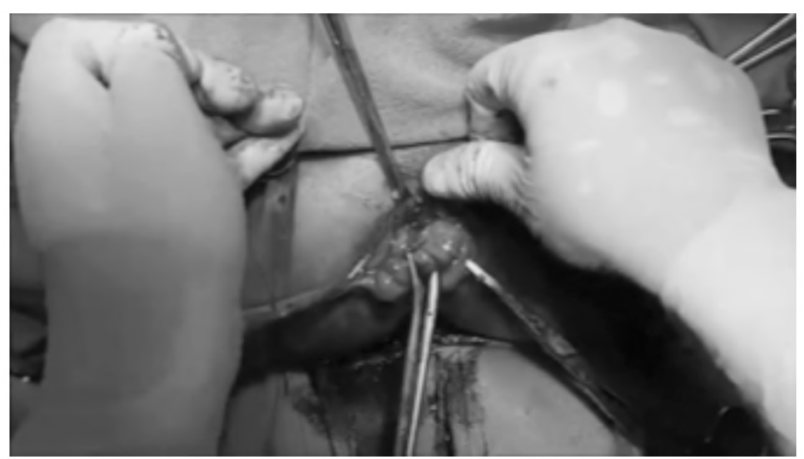

(B)

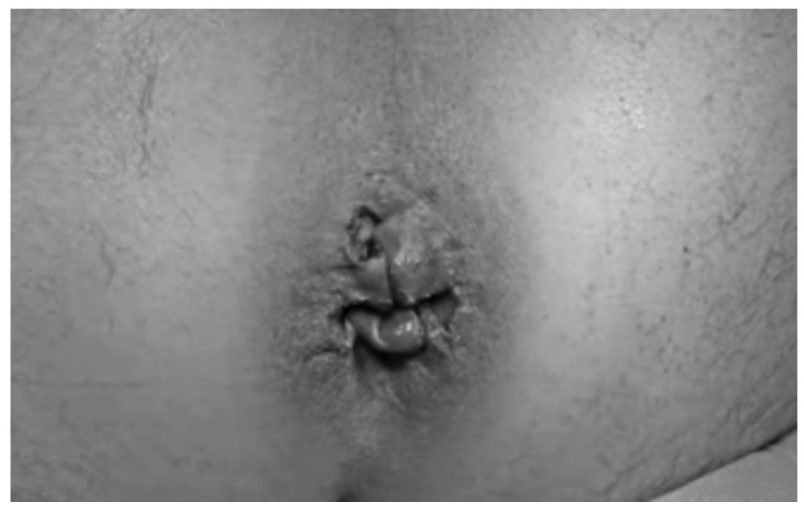

(D)

Fig. (1): Open (Milligan morgan) hemorrhoidectomy.

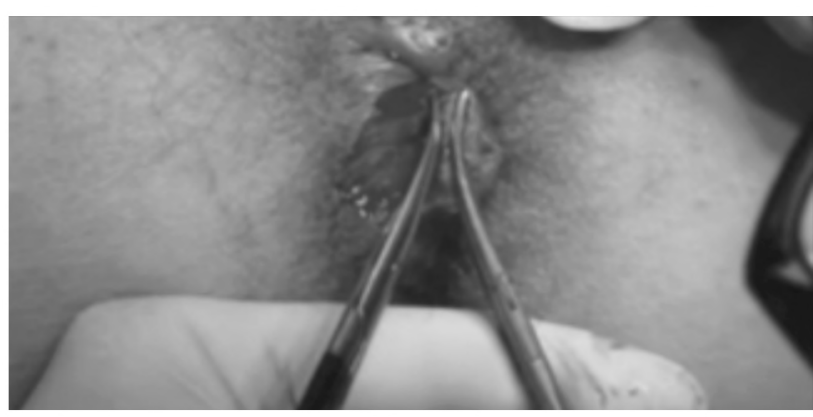

(A)

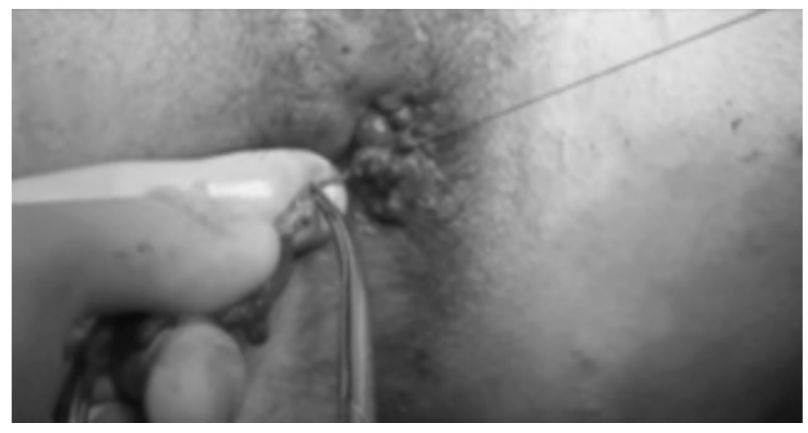

(C)

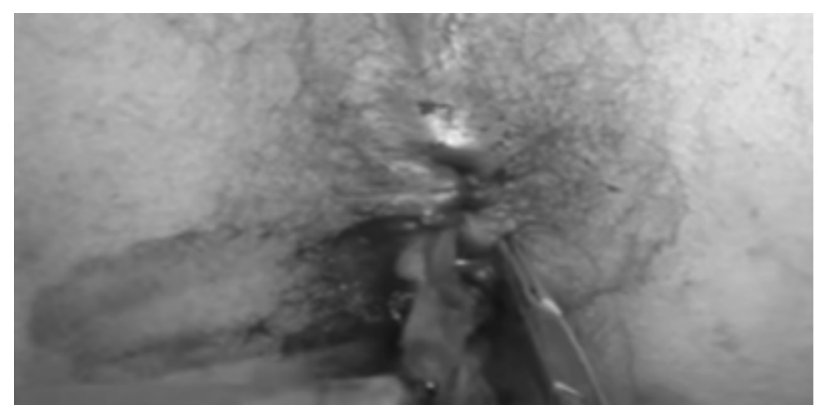

(B)

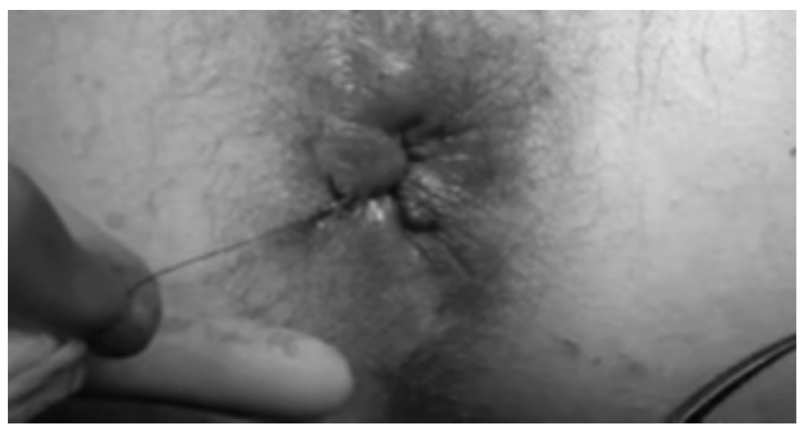

(D)

Fig. (2): Closed (Ferguson) hemorrhoidectomy. 

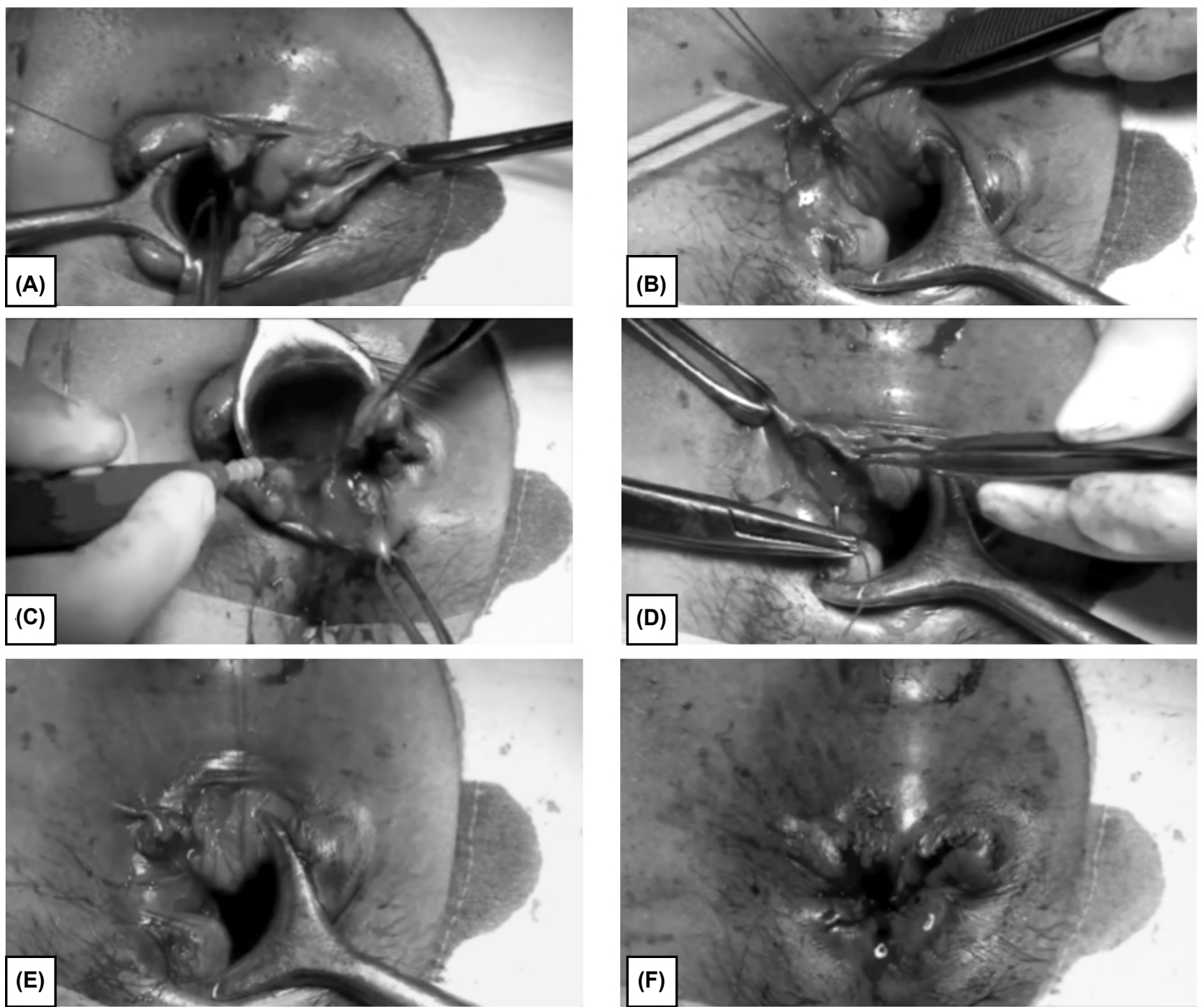

Fig. (3): Closed Hemorrhoidectomy with plication.
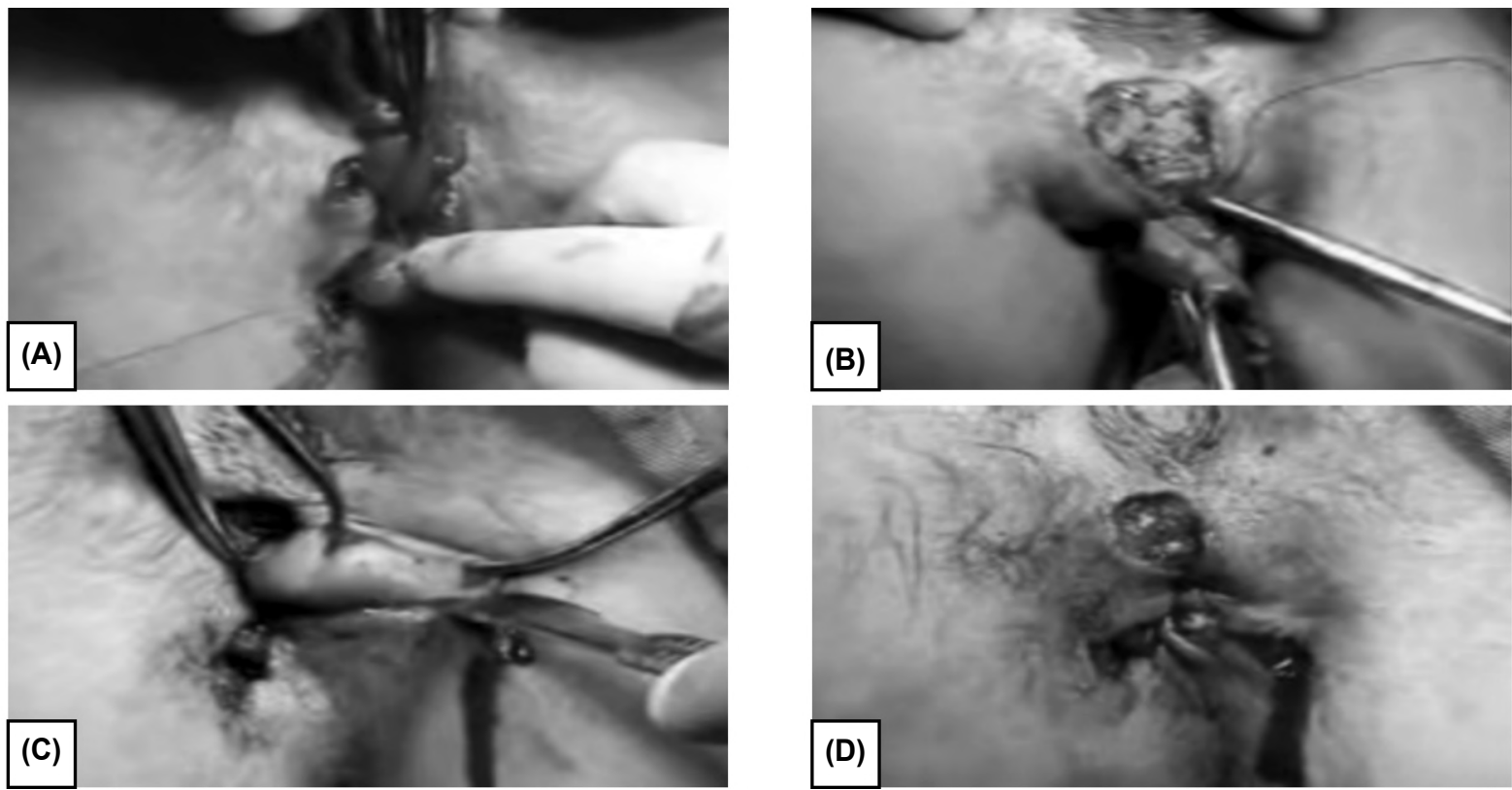

Fig. (4): Open Hemorrhoidectomy with plication 


\section{Postoperative assessment:}

1- The pain in postoperative period was assessed by visual analog scale (VAS) with a rating ranging from $0-10$.

2- Post-operative bleeding was mentioned in case it happened.

3- Regular follow-up and examination of the patients in both groups was done (1) 12 hours after surgery. (2) 24 hours after surgery (3) 48 hours after surgery.

Study interventions:

\section{Therapeutic intervention.}

\section{Statistical analysis:}

Data were collected, revised, coded and entered to the Statistical Package for Social Science (IBM SPSS) version 20. The qualitative data were presented as number and percentages while quantitative data were presented as mean, standard deviations and ranges when their distribution found parametric.

The comparison between two groups with qualitative data were done by using Chi-square test and/or Fisher exact test was used instead of Chisquare test when the expected count in any cell was found less than 5 .

The comparison between more than two independent groups with quantitative data and parametric distribution was done by using One Way ANOVA Test.

The confidence interval was set to $95 \%$ and the margin of error accepted was set to 5\%. So, the pvalue was considered significant as the following: $p>0.05=$ Non-significant (NS), $p<0.05=$ Significant $(\mathrm{S})$ and $p<0.001=$ Highly significant (HS).

\section{Results}

Mean age was 41.20, 41.60, $40.60 \& 40.44$ years among the group of Open without plication, Open with plication, Closed without plication \& Closed with plication respectively, while the male $\%$ was $40 \%$ in all groups, positive family history was predicted in $8 \%, 4 \%, 8 \%$ \& $8 \%$ respectively. And there was non statistically significant difference found between 4 groups regarding Age, Sex, Marital status and Family history.

More than $50 \%$ of our population had firstdegree haemorrhoids \& the rest of population had 2 nd degree haemorrhoids, anal pain was presented in $60 \%, 56 \%, 48 \% \& 72 \%$ of the group of Open without plication, Open with plication, Closed without plication \& Closed with plication respectively. And there was no significant statistical difference between 4 groups regarding ASA classification, previous medications \& Degree of haemorrhoids.

The number of fully socked gauzes was 1 in more than 60 of all groups while it was 2 in $36 \%$, $32 \%, 36 \%$ \& $24 \%$ the group of Open without plication, Open with plication, Closed without plication \& Closed with plication respectively. And there was non statistically significant difference found between 4 groups regarding Dressing number (number of fully socked gauzes).

Minimal blood loss happened in more than $60 \%$ of all study population, mean duration of Postoperative pain was less than 4 hours in the 4 groups $\&$ there was non statistically significant difference found between 4 groups regarding Blood loss, Post operative pain 12 hours, Post operative pain 24 hours and Post operative pain 48 hours.

Mean day of wound healing among our patients was around 7 th day while discharge stopped around the 2 nd day, there was non statistically significant difference found between 4 groups regarding the day of wound healing and Discharge stoppage.

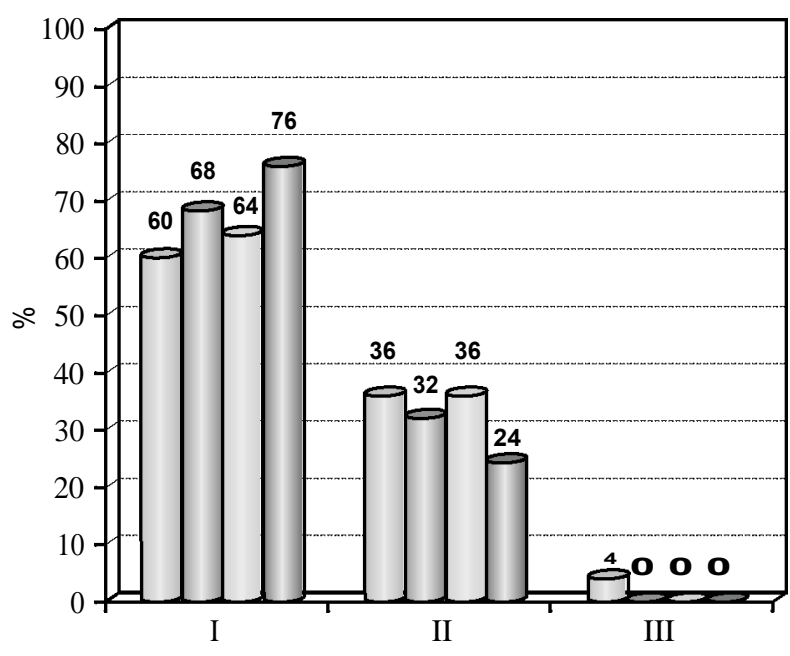

Dressing number (number of fully socked gozes)

$$
\begin{aligned}
& \text { 二 Open without plication } \\
& \text { ニ Open with plication } \\
& \text { Z Closed without plication } \\
& \square \text { Closed with plication }
\end{aligned}
$$

Fig. (5): Number of fully socked gauzes in the 4 groups. 


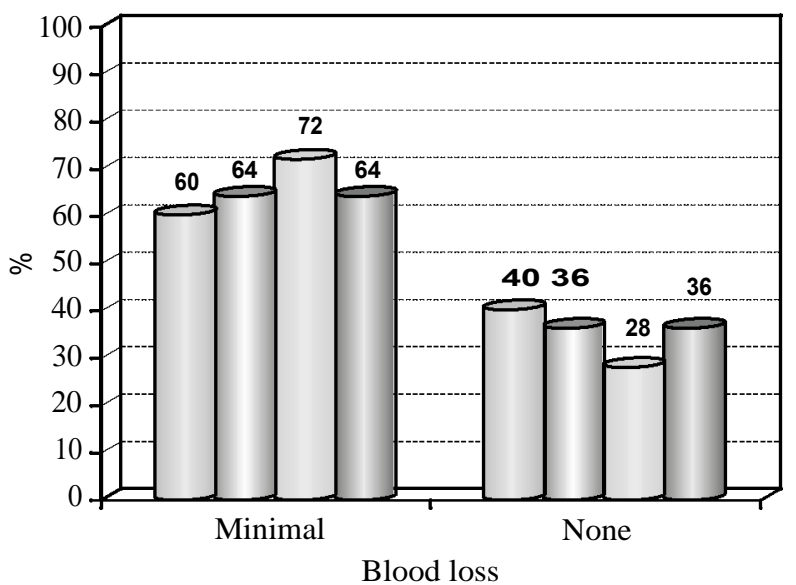

Open without plication

Open with plication

Closed without plication

Closed with plication

Fig. (6): Blood loss in the 4 groups.
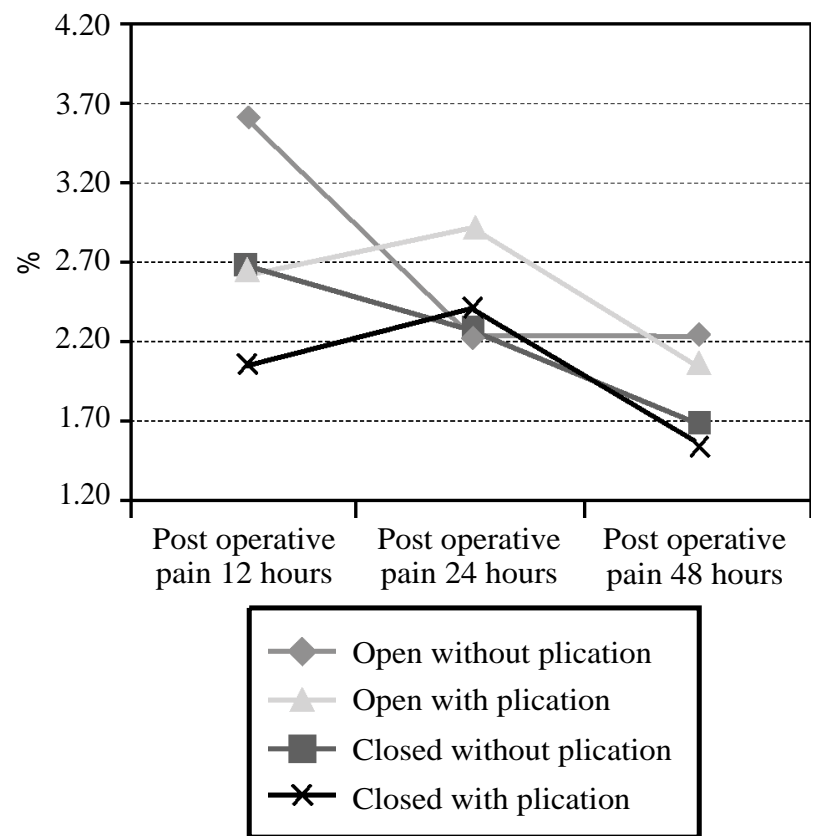

Fig. (7): Post-operative pain in the 4 groups.

Table (1): Demographic data of study population.

\begin{tabular}{|c|c|c|c|c|c|c|}
\hline & $\begin{array}{l}\text { Open without } \\
\text { plication }\end{array}$ & $\begin{array}{l}\text { Open with } \\
\text { plication }\end{array}$ & $\begin{array}{l}\text { Closed without } \\
\text { plication }\end{array}$ & $\begin{array}{l}\text { Closed with } \\
\text { plication }\end{array}$ & \multirow{2}{*}{$\begin{array}{c}\text { Test } \\
\text { value }\end{array}$} & \multirow{2}{*}{$\begin{array}{c}p- \\
\text { value }\end{array}$} \\
\hline & No. $=25$ & No. $=25$ & No. $=25$ & No. $=25$ & & \\
\hline \multicolumn{7}{|l|}{ Age: } \\
\hline Mean \pm SD & $41.20 \pm 9.54$ & $41.60 \pm 8.90$ & $40.60 \pm 8.07$ & $40.44 \pm 10.02$ & $0.086 \bullet$ & 0.968 \\
\hline Range & $23-55$ & $23-55$ & $27-55$ & $23-55$ & & \\
\hline \multicolumn{7}{|l|}{ Sex: } \\
\hline Female & $15(60 \%)$ & $15(60 \%)$ & $15(60 \%)$ & $15(60 \%)$ & $0.000 *$ & 1.000 \\
\hline Male & $10(40 \%)$ & $10(40 \%)$ & $10(40 \%)$ & $10(40 \%)$ & & \\
\hline \multicolumn{7}{|l|}{ Marital status: } \\
\hline Divorced & $0(0 \%)$ & $0(0 \%)$ & $1(4 \%)$ & $2(8 \%)$ & $7.724 *$ & 0.259 \\
\hline Married & $12(48 \%)$ & $17(68 \%)$ & $17(68 \%)$ & $12(48 \%)$ & & \\
\hline Single & $13(52 \%)$ & $8(32 \%)$ & $7(28 \%)$ & $11(44 \%)$ & & \\
\hline \multicolumn{7}{|l|}{ Family history: } \\
\hline No & $23(92 \%)$ & $24(96 \%)$ & $23(92 \%$ & $23(92 \%)$ & $0.461 *$ & 0.927 \\
\hline Yes & $2(8 \%)$ & $1(4 \%)$ & $2(8 \%)$ & $2(8 \%)$ & & \\
\hline
\end{tabular}

$p$-value $>0.05$ : Non significant (NS).

$p$-value $<0.05$ : Significant (S).

$p$-value <0.01: Highly significant (HS).

$*$ : Chi-square test.

•: One Way ANOVA Test. 
Table (2): Pre-operative presentations among study groups.

\begin{tabular}{|c|c|c|c|c|c|c|c|c|c|c|}
\hline \multirow{2}{*}{ Pre operative } & \multicolumn{2}{|c|}{$\begin{array}{l}\text { Open without } \\
\text { plication }\end{array}$} & \multicolumn{2}{|c|}{$\begin{array}{l}\text { Open with } \\
\text { plication }\end{array}$} & \multicolumn{2}{|c|}{$\begin{array}{l}\text { Closed without } \\
\text { plication }\end{array}$} & \multicolumn{2}{|c|}{$\begin{array}{l}\text { Closed with } \\
\text { plication }\end{array}$} & \multirow{2}{*}{$\begin{array}{c}\text { Test } \\
\text { value* }\end{array}$} & \multirow{2}{*}{$\begin{array}{c}p- \\
\text { value }\end{array}$} \\
\hline & No. & $\%$ & No. & $\%$ & No. & $\%$ & No. & $\%$ & & \\
\hline \multicolumn{11}{|c|}{ ASA classification: } \\
\hline I & 15 & 60 & 14 & 56 & 15 & 60 & 14 & 56 & 0.164 & 0.983 \\
\hline II & 10 & 40 & 11 & 44 & 10 & 40 & 11 & 44 & & \\
\hline III & 0 & 0 & 0 & 0 & 0 & 0 & 0 & 0 & & \\
\hline \multicolumn{11}{|c|}{ Previous medications: } \\
\hline No & 20 & 80 & 19 & 76 & 19 & 76 & 19 & 76 & 0.169 & 0.982 \\
\hline Yes & 5 & 20 & 6 & 24 & 6 & 24 & 6 & 24 & & \\
\hline \multicolumn{11}{|l|}{ Anal pain: } \\
\hline No & 10 & 40 & 11 & 44 & 13 & 52 & 7 & 28 & 3.100 & 0.376 \\
\hline Yes & 15 & 60 & 14 & 56 & 12 & 48 & 18 & 72 & & \\
\hline \multicolumn{11}{|c|}{ Anal discharge: } \\
\hline No & 25 & 100 & 25 & 100 & 25 & 100 & 25 & 100 & - & - \\
\hline Yes & 0 & 0 & 0 & 0 & 0 & 0 & 0 & 0 & & \\
\hline \multicolumn{11}{|l|}{ Anal bleeding: } \\
\hline No & 18 & 72 & 17 & 68 & 18 & 72 & 17 & 68 & 0.190 & 0.979 \\
\hline Yes & 7 & 28 & 8 & 32 & 7 & 28 & 8 & 32 & & \\
\hline \multicolumn{11}{|c|}{ Perianal dermatitis (pururitis): } \\
\hline No & 21 & 84 & 22 & 88 & 20 & 80 & 23 & 92 & 1.661 & 0.646 \\
\hline Yes & 4 & 16 & 3 & 12 & 5 & 20 & 2 & 8 & & \\
\hline \multicolumn{11}{|l|}{ Degree: } \\
\hline III & 14 & 56 & 13 & 52 & 13 & 52 & 14 & 56 & 0.161 & 0.984 \\
\hline IV & 11 & 44 & 12 & 48 & 12 & 48 & 11 & 44 & & \\
\hline
\end{tabular}

Table (3): Assessment of intraoperative bleeding among study groups.

\begin{tabular}{|c|c|c|c|c|c|c|c|c|c|c|}
\hline \multirow{2}{*}{ Intra operative } & \multicolumn{2}{|c|}{$\begin{array}{l}\text { Open without } \\
\text { plication }\end{array}$} & \multicolumn{2}{|c|}{$\begin{array}{l}\text { Open with } \\
\text { plication }\end{array}$} & \multicolumn{2}{|c|}{$\begin{array}{l}\text { Closed without } \\
\text { plication }\end{array}$} & \multicolumn{2}{|c|}{$\begin{array}{l}\text { Closed with } \\
\text { plication }\end{array}$} & \multirow{2}{*}{$\begin{array}{c}\text { Test } \\
\text { value* }\end{array}$} & \multirow{2}{*}{$\begin{array}{c}p- \\
\text { value }\end{array}$} \\
\hline & No. & $\%$ & No. & $\%$ & No. & $\%$ & No. & $\%$ & & \\
\hline \multicolumn{11}{|c|}{$\begin{array}{l}\text { Dressing number } \\
\text { (number of fully } \\
\text { socked gozes): }\end{array}$} \\
\hline $\begin{array}{l}\text { I } \\
\text { II } \\
\text { III }\end{array}$ & $\begin{array}{l}15 \\
9 \\
1\end{array}$ & $\begin{array}{l}60 \\
36 \\
4\end{array}$ & $\begin{array}{l}17 \\
8 \\
0\end{array}$ & $\begin{array}{l}68 \\
32 \\
0\end{array}$ & $\begin{array}{l}16 \\
9 \\
0\end{array}$ & $\begin{array}{l}64 \\
36 \\
0\end{array}$ & $\begin{array}{l}19 \\
6 \\
0\end{array}$ & $\begin{array}{l}76 \\
24 \\
0\end{array}$ & 4.272 & 0.640 \\
\hline
\end{tabular}

$p$-value $>0.05$ : Non significant (NS).

$p$-value $<0.05$ : Significant $(\mathrm{S})$.

$p$-value $<0.01$ : Highly significant (HS).

*: Chi-square test.

•: One Way ANOVA Test. 
Table (4): Comparison between study groups regarding post-operative values.

\begin{tabular}{|c|c|c|c|c|c|c|}
\hline Post operative & $\begin{array}{l}\text { Open without } \\
\text { plication }\end{array}$ & $\begin{array}{l}\text { Open with } \\
\text { plication }\end{array}$ & $\begin{array}{l}\text { Closed without } \\
\text { plication }\end{array}$ & $\begin{array}{l}\text { Closed with } \\
\text { plication }\end{array}$ & \multirow[t]{2}{*}{$\begin{array}{c}\text { Test } \\
\text { value }\end{array}$} & \multirow[t]{2}{*}{$\begin{array}{c}p- \\
\text { value }\end{array}$} \\
\hline & No. $=25$ & No. $=25$ & No. $=25$ & No. $=25$ & & \\
\hline $\begin{array}{l}\text { Blood loss: } \\
\text { Minimal } \\
\text { None }\end{array}$ & $\begin{array}{l}15(60 \%) \\
10(40 \%)\end{array}$ & $\begin{array}{l}16(64 \%) \\
9(36 \%)\end{array}$ & $\begin{array}{l}18(72 \%) \\
7(28 \%)\end{array}$ & $\begin{array}{l}16(64 \%) \\
9(36 \%)\end{array}$ & $0.835^{*}$ & 0.841 \\
\hline $\begin{array}{l}\text { Post operative } \\
\text { pain } 12 \text { hours: } \\
\text { Mean } \pm \mathrm{SD} \\
\text { Range }\end{array}$ & $\begin{array}{l}3.60 \pm 2.87 \\
0-8\end{array}$ & $\begin{array}{l}2.68 \pm 2.91 \\
0-9\end{array}$ & $\begin{array}{l}2.64 \pm 2.20 \\
0-6\end{array}$ & $\begin{array}{l}2.04 \pm 2.57 \\
0-8\end{array}$ & $1.471 \bullet$ & 0.227 \\
\hline $\begin{array}{l}\text { Post operative } \\
\text { pain } 24 \text { hours: } \\
\text { Mean } \pm \text { SD } \\
\text { Range }\end{array}$ & $\begin{array}{l}2.24 \pm 1.90 \\
0-5\end{array}$ & $\begin{array}{l}2.28 \pm 2.32 \\
0-6\end{array}$ & $\begin{array}{l}2.92 \pm 2.75 \\
0-7\end{array}$ & $\begin{array}{l}2.40 \pm 3.03 \\
0-7\end{array}$ & $0.384 \bullet$ & 0.765 \\
\hline $\begin{array}{l}\text { Post operative } \\
\text { pain } 48 \text { hours: } \\
\text { Mean } \pm \text { SD } \\
\text { Range }\end{array}$ & $\begin{array}{l}2.24 \pm 3.15 \\
0-8\end{array}$ & $\begin{array}{l}1.68 \pm 2.56 \\
0-8\end{array}$ & $\begin{array}{l}2.04 \pm 2.49 \\
0-7\end{array}$ & $\begin{array}{l}1.56 \pm 2.12 \\
0-6\end{array}$ & $0.365 \bullet$ & 0.779 \\
\hline
\end{tabular}

Table (5): Comparison between study groups regarding Time of Complete wound healing and Discharge stoppage.

\begin{tabular}{|c|c|c|c|c|c|c|}
\hline Post operative & $\begin{array}{l}\text { Open without } \\
\text { plication }\end{array}$ & $\begin{array}{l}\text { Open with } \\
\text { plication }\end{array}$ & $\begin{array}{l}\text { Closed without } \\
\text { plication }\end{array}$ & $\begin{array}{l}\text { Closed with } \\
\text { plication }\end{array}$ & \multirow[t]{2}{*}{$\begin{array}{c}\text { Test } \\
\text { value }\end{array}$} & \multirow[t]{2}{*}{$\begin{array}{c}p- \\
\text { value }\end{array}$} \\
\hline & No. $=25$ & No. $=25$ & No. $=25$ & No. $=25$ & & \\
\hline \multicolumn{7}{|c|}{ The day of wound healing: } \\
\hline Mean \pm SD & $7.20 \pm 1.50$ & $6.96 \pm 1.51$ & $7.52 \pm 1.45$ & $7.04 \pm 1.67$ & $0.651 \bullet$ & 0.584 \\
\hline Range & $4-9$ & $4-9$ & $5-9$ & $4-9$ & & \\
\hline \multicolumn{7}{|c|}{ Discharge stoppage: } \\
\hline Mean $\pm \mathrm{SD}$ & $3.27 \pm 1.90$ & $2.86 \pm 1.29$ & $2.70 \pm 1.57$ & $2.33 \pm 0.49$ & $0.903 \bullet$ & 0.447 \\
\hline Range & $2-7$ & $2-7$ & $2-7$ & $2-3$ & & \\
\hline
\end{tabular}

\section{Discussion}

Haemorrhoids are specialized, highly vascularized 'cushions' forming discrete masses of thick sub-mucosa containing blood vessels, smooth muscles and elastic and connective tissues limited to the anal canal and perianal area. The cause of haemorrhoids remains unknown. Numerous factors contribute to haemorrhoidal diseases such as constipation, prolonged squatting, pregnancy, aging, hereditary, portal hypertension, abdominal tumor and defecation habits [1]

The treatment of haemorrhoids remains challenging: Multiple treatment options supported by heterogeneous evidence are available, but patients rightly demand a tailored approach. Evidence for newer surgical techniques that promise to be less painful has been conflicting [9].

Third-degree hemorrhoids have traditionally been removed by haemorrhoidectomy. A variety of techniques have been described. Currently, 2 methods of haemorrhoidectomy are popular: The (Milligan and Morgan) open excision, and the (Ferguson) closed haemorrhoidectomy [5]. In both approaches, the underlying principle is to remove the swollen haemorrhoid tissue from outside and inside the anal canal, preserving sufficient mucosa and anoderm to maintain function of the anal canal. Haemorrhoidectomy can be performed with scissors or diathermy; more recently, other energy devices have been used including ultrasonic technology 
(Harmonic scalpel), laser, and radiofrequency devices, with reports that these newer technologies cause less postoperative pain and allow quicker return to normal activity [9].

Plication of piles appears to have significant advantages over conventional methods in terms of patient comfort, duration of stay in hospital and incidence of complications [10].

This study aimed to assess the effectiveness of plication in reduction of postoperative pain and bleeding after open and closed hemorrhoidectomy, to detect the best method in surgical management of hemorrhoid \& to correlate between plication and incidence of postoperative pain and bleeding.

To obtain this aim, we included 100 patients who underwent haemorrhoidectomy at Surgery Department of Ain Shams University Hospitals \& El-Mahalla general hospital. Then we divided them into 4 groups each group contained 25 patients. Each of the 4 groups underwent one of the following surgeries:

1- Group 1: Open haemorrhoidectomy without plication.

2- Group 2: Open haemorrhoidectomy with plication.

3- Group 3: Closed haemorrhoidectomy without plication.

4- Group 4: Closed haemorrhoidectomy with plication.

In Shaikh et al., [11] study, 110 patients in group A were operated by an open method and 103 patients in group B were operated by closed method.

In Uba et al., [12] study, Consecutive patients who presented with second and third degree hemorrhoids were randomized into an open group and a closed group.

Male $\%$ among our population was $40 \%$, average age was 40 years, there was non-significant statistical difference in the current study between 4 groups regarding Age, Sex, Marital status and Family history.

Total 1014 patients of piles were selected for plication and conventional haemorrhoidectomy and most of them were between 31-50 years of age while 362 cases underwent plication, rest 346 cases were treated with haemorrhoidectomy in Pattanayak et al., [10] study.
136 patients who were suffering from haemorrhoids \& fissures were included in Singh et al., [1] study. Of these 84 patients were operated by open technique and 52 patients by close technique.

Total 50 patients of piles were included in Agarwal et al., [13] study and most of the patients were between $31-50$ years of age $(60 \%)$ with males preponderance.

Age of patients ranged from 22-70 years in Shaikh et al., [11] study with mean age of 45.5 years. Peak incidence was between $41-50$ years. Out of 213 patients, $170(79.81 \%)$ were male and $43(20.18 \%)$ were females.

There were 59 males and 20 females in Uba et al., [12] study, distributed between open group $(n=39)$ and close group $(n=40)$.

The mean age of Arroyo et al., [14] population was 43.5 years. There was a predominance of males $(61.5 \%)$ with no gender differences.

More than $50 \%$ of our total population had first-degree hemorrhoids\& the rest of population had 2 nd degree hemorrhoids, there was nonsignificant statistical difference between 4 groups regarding ASA classification, previous medications $\&$ Degree of hemorrhoids.

Out of 507 patients which has been examined for plication in Pattanayak et al., [10] study, 272 $(53.65 \%)$ had 2 nd degree, $235(46.35 \%)$ had 3 rd degree piles.

Out of 50 patients included in Agarwal et al., [13] study, 38\% had ${ }^{1 \text { st }}$ degree piles, 58\% had 2 nd degree piles and rest had 3 rd degree piles, $60 \%$ of patients received some form of conservative treatment and partially relieved.

Shaikh et al., [11] study included 213 patients with late 2 nd degree; third or fourth degree hemorrhoids were assigned to two groups.

87.5\% of Arroyo et al., [14] patients had thirdfourth degree piles. The anesthetic risk in Arroyo et al., [14] study was ASA I-II in $88 \%$ of the patients and ASA III in $12 \%$. There were not significant differences between the two groups in the characteristics of patients.

There was non-significant statistical difference between 4 groups in the current study regarding symptoms; anal pain was presented in $60 \%, 56 \%$, $48 \%$ \& $72 \%$ of patients in group $1,2,3 \& 4$ respectively. While anal Bleeding was reported in $28 \%, 32 \%, 28 \% \& 32 \%$ of patients in group 1,2 , 
3 \& 4 respectively, \& Perianal dermatitis was reported in $16 \%, 12 \%, 20 \% \& 8 \%$ of patients in group 1, 2, $3 \& 4$ respectively.

All patients in Pattanayak et al., [10] \& Agarwal et al., [13] studies had bleeding per rectum as the main symptom.

In Shaikh et al., [11] study, patients presented with a variety of symptoms including bleeding per rectum, prolapse of mass per rectum, constipation, discharge, itching and anemia. The main complaint was bleeding and prolapse of mass per rectum i.e. $100 \%$ of cases. Bleeding was mostly in the form of streaming of drops in both groups. Constipation was also present in 78 patients $(70.90 \%)$ in open Group, and 90 patients $(87.37 \%$ ) in close Group; $(p=0.03)$. Itching was present in 76 patients $(69.09 \%)$ in open Group, and 68 patients $(66.01 \%)$ in close Group; $(p=0.03)$.

In contrary to our study, Clinical presentation in Arroyo et al., [14] study included 95\% rectal bleeding.

In this study, Perianal swelling \& anal discharge were not reported among our patients in the 4 groups as a presenting symptom.

In contrary to our study, Shaikh et al., [11] reported that discharge was present in 71 patients (64.54\%) in open Group, and 79 patients (76.69\%) in close Group; $(p=0.04)$.

According to our study, there was nonsignificant statistical difference between 4 groups regarding Dressing number (number of fully socked gozes).

Similar to our result, Johannsson et al., [15] reported that there was no significant difference between the groups in the complications $(p=0.067)$; however, $1.7 \%$ of patients in the Milligan-Morgan group needed a reoperation because of bleeding, the corresponding value for the 110 patients in the Ferguson group was $3.6 \%$ for bleeding.

According to the current study, there was nonsignificant statistical difference between 4 groups regarding post-operative pain 12 hours, postoperative pain 24 hours and post-operative pain 48 hours.

While results of plication of piles were satisfactory and only $4 \%$ patients had pain for which long term analgesics were given as reported by [10].
In Agarwal et al., [13] study of plication of piles, $94 \%$ of cases had no pain, $6 \%$ of cases who had pain were also suffering from fissure. The results of plication of piles are satisfactory and only $2 \%$ of the patients had pain for which long term analgesics were given.

In both close \& open procedures, no patient was pain free. However, Post-operative pain scores were significantly low in the open Group than close Group during first 24 hours $(p=0.02)$, as reported by Shaikh et al., [11].

Similar to our result, Johannsson et al., [15] reported No significant difference in postoperative pain was noted between the groups, except at day $13(p=0.041)$.

In contrary to our result, reported that Arroyo et al., [14] Postoperative pain during the first postoperative week was greater in the open haemorrhoidectomy group, but the difference was statistically significant $(p<0.05)$ only during bowel movements.

In our study, Minimal intraoperative Blood loss occurred in $60 \%, 64 \%, 72 \%$ \& $64 \%$ of patients in group 1, 2, 3 \& 4 respectively with no significant difference between the 4 groups.

According to Singh et al., [1] study, Peroperative hemorrhage in close group was less.

In concordance with our study, Uba et al., [12] reported that there were no differences in the complication rate between the two groups included in study.

In the current study, Mean duration of wound healing was $7.20 \pm 1.50,6.96 \pm 1.51,7.52 \pm 1.45 \&$ $7.04 \pm 1.67$ days among patients in group $1,2,3$ \& 4 respectively with no significant difference between the 4 groups.

Wound healing was quicker in close group than the open group ( $p=0.03)$, as reported by Shaikh et al., [11].

In contrary to our study, the average wound healing time in Uba et al., [12] study was significantly shorter in close group ( 2.8 vs 5.0 weeks).

That was in discordance with Arroyo et al., [14], as at the end of the first month, there was complete healing in $40 \%$ of the patients in open group and $90 \%$ of those in close group $(p<0.05)$. 
In the present study, Mean duration till Discharge stopped was $3.27 \pm 1.90,2.86 \pm 1.29,2.70 \pm$ $1.57 \& 2.33 \pm 0.49$ days among patients in group 1 , $2,3 \& 4$ respectively with no significant difference between the 4 groups.

According to Shaikh et al., [11] study, wound infection was one $(0.9 \%)$ in open group and two $(1.9 \%)$ in close group with no significant difference between both groups.

\section{Conclusion:}

According to our study results, we can conclude thatplication of piles appears to have no significant advantages over conventional methods in terms of patient comfort and incidence of intraoperative \& postoperative complications.

\section{References}

1- SINGH R., REDDY T.R. and KUMAR T.S.: A comparative study of open (Milligan-Morgan) versus closed d (Ferguson) hemorrhoidectomy with and without internal sphincterotomy. International Surgery Journal, 6 (2): 443-446, 2019.

2- AGRAWAL S. and CHOPRA S.: Comparative study between conventional hemorrhoidectomy versus stapled hemorrhoidopexy at Ja Group of Hospitals Gwalior. IOSR J. Dental Med. Sci., 15 (12): 69-94, 2016.

3- CARO A., OLONA C., VICENTE V., GONCALVES C. and JIMENEZ A.: Grade 3 haemorrhoidal treatment: Rubber band ligation or hemorrhoidectomy-a prospective study. Ambulatory, 13, 56, 2009.

4- WILLIAMS N.S.: The anus and anal canal. In: Bailey and Love's Short Practice of Surgery. 27 th Ed. Boca Raton: FL, 1354-1361, 2018.

5- ALTOMARE D.F. and GIURATRABOCCHETTA S.: Conservative and surgical treatment of hemorrhoids. Nature Reviews Gastroenterology \& Hepatology, 10 (9): 513, 2013.
6- LEE K.C., LIU C.C., HU W.H., LU C.C., LIN S.E. and CHEN H.H.: Risk of delayed bleeding after hemorrhoidectomy. International journal of colorectal disease, 34 (2): 247-253, 2019.

7- POKHAREL N., CHHETRI R.K., MALLA B., JOSHI H.N. and SHRESTHA R.K.: Hemorrhoidectomy: Ferguson's (closed d) Vs Milligan = Morgan's technique (open). Nepal Med. Coll. J., 11 (2): 136-7, 2009.

8- KHUBCHANDANI I.T.: Internal sphincterotomy with hemorrhoidectomy does not relieve pain. Diseases of the colon \& rectum, 45 (11): 452-1457, 2002.

9- NG K.S., HOLZGANG M. and YOUNG C.: Still a case of "no pain, no gain"? An updated and critical review of the pathogenesis, diagnosis, and management options for hemorrhoids in 2020. Annals of Coloproctology, 36 (3): 133, 2020.

10- PATTANAYAK S., KUMAR M., PATRO S.K. and BEHERA M.K.: Plication: An innovative method of treating piles. International Surgery Journal, 6 (11): 4056-4061, 2019.

11- SHAIKH A.R., DALWANI A.G. and SOOMRO N.: An evaluation of milligan-morgan and Ferguson procedures for haemorrhoidectomy at Liaquat University hospital Jamshoro, Hyderabad, Pakistan. Pakistan Journal of Medical Sciences, 29 (1): 122, 2013.

12- UBA A.F., OBEKPA P.O. and ARDILL W.: Open versus closed haemorrhoidectomy. The Nigerian Postgraduate Medical Journal, 11 (2): 79-83, 2004.

13- AGARWAL S., MEHTA R. and JOSHI C.P.: A study on plication of piles. International Surgery Journal, 3 (2): 786-791, 2016.

14- ARROYO A., PEREZ F., MIRANDA E., SERRANO P., CANDELA F. and LACUEVA J.: Open versus closed day-case haemorrhoidectomy: Is there any difference? Results of a prospective randomized study. Int. J. Colorectal Dis., 19 (4): 370-373, 2004.

15- JOHANNSSON H.O., PAHLMAN L. and GRAF W.: Randomized clinical trial of the effects on anal function of Milligan-Morgan versus Ferguson haemorrhoidectomy. Br. J. Surg., 93 (10): 1208-1214, 2006. 


\section{دراسة مقارنة بين استئصال البواسير

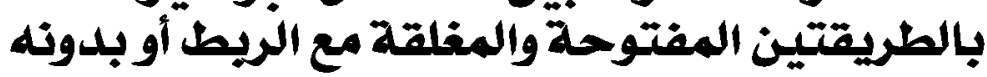

تعتبر البواسير عادة أكثر أمراض الشرج إزعاجاً. فهى من الممكن أن نتزلق، وتدلى، وتتوسع، وتنزف من حين لآخر ، يتأثر بها ملايين

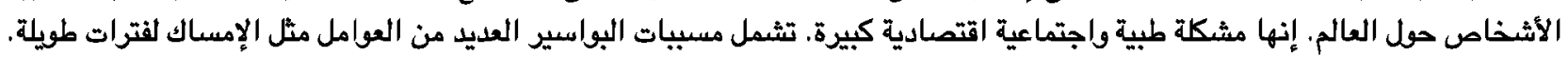

هدفت هذه الدراسة: إلى تقييم فعالية الطى فى الحد من آلام ما بعد الجراحة والنزيف بعد استئمال البواسير المفتوحة والمغلقة المقارنة

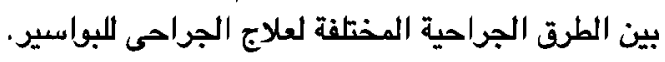

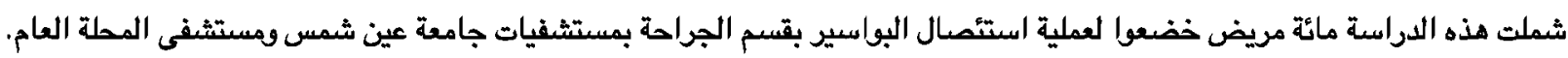

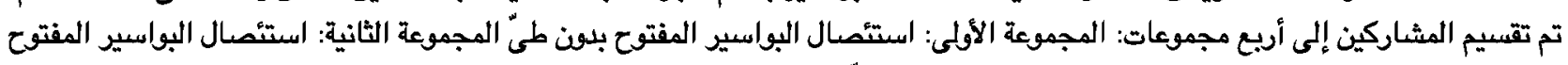

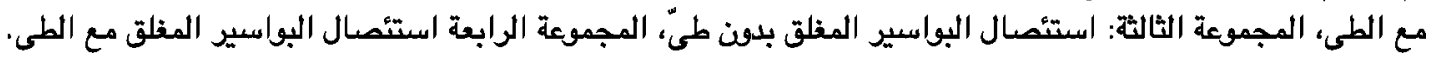

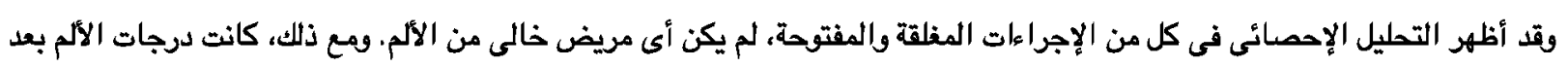

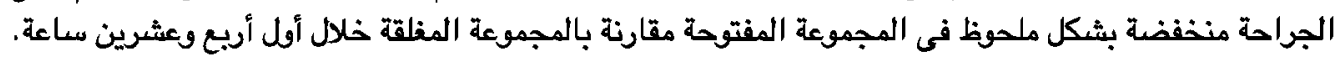

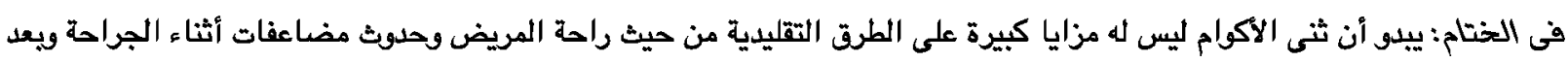
العملية الجراحية. كما لا توجد فرق الثق جوهرية بين الطرق الجراحية المختلفة لعلاج البواسير. 